\title{
Genome-wide screens - a systematic approach to redefine the influenza A virus-host crosstalk
}

\author{
Adarsh K. Mayank ${ }^{2 \dagger}$, Shipra Sharma ${ }^{1 \dagger}$, Ravi K Deshwal ${ }^{3}$ and Sunil K. Lal ${ }^{1 *}$ \\ *Correspondence: sunillal@icgeb.res.in \\ CrossMark \\ \& Click for updates \\ 'These authors contributed equally to this work. \\ 'Virology Group, International Centre for Genetic Engineering and Biotechnology, Aruna Asaf Ali Marg, New Delhi, India. \\ ${ }^{2}$ Research Scholar, Singhania University, Rajasthan. \\ ${ }^{3}$ Apex Institute of Management and Science, Jaipur, Rajasthan.
}

\begin{abstract}
Influenza A viruses belong to Orthomyxoviridae family and are known to cause infection in humans as well as a variety of mammals and birds. The virus is transmitted between diverse species where it extensively utilizes the host biology for its evolution into new pandemic strains. Not surprisingly, many aspects of the life cycle of Influenza A virus are intimately linked to the functions of host cellular proteins and RNAs. Recent discoveries of viral and cellular factors mediating virus-host interactions have allowed scientists to unravel the key molecular mechanisms of viral infection and escape from innate and adaptive immune responses. Recent technological advancements and usage of genome-wide screens will help in identification of cellular proteins that assist or restrict Influenza A virus life cycle, which in turn will not only further our current understanding of the molecular pathogenesis of Influenza infection but also help to develop novel targets of antiviral strategies. In this review we summarize the techniques used to identify host factors and examine the possible roles of the genes and pathways identified in the viral life cycle.
\end{abstract}

Keywords: Influenza, genome-wide, RNAi screening, mass spectrometry

\section{Introduction}

Influenza, commonly referred to as the flu, is an infectious disease caused by RNA viruses of the family Orthomyxoviridae (the influenza viruses), that infects birds and mammals. Influenza virus causes annual epidemics and occasional pandemics due to its contagious nature and high mutation rate [1]. These epidemics claims 250000 to 500000 lives each year worldwide (www.who.int/csr/disease/swineflu/updates). Pandemics are highly deadly. For instance, the notorious 1918-1919 Spanish flu killed at least 50 million people, and the most recent Hong Kong Flu in 1968 killed about 1 million people worldwide [2-4]

There are three kinds of Influenza virus: A, B and C, of which type $A$ viruses are the most virulent human pathogens, causing disease of maximum severity. Wild aquatic birds are natural hosts of influenza A virus. Occasionally, viruses are transmitted to other species and may often cause devastating outbreaks in domestic poultry or give rise to human influenza pandemics [5-7].

Influenza A virus particle is made up of a viral envelope containing hemagglutinin and neuraminidase glycoproteins, wrapped around a central core. The central core contains eight segments of negative sense RNA genome and other viral proteins that package and protect viral RNA $[8,9]$. The viral RNA genome encodes 11 proteins: hemagglutinin (HA), neuraminidase (NA), nucleoprotein (NP), matrix protein 1 (M1), matrix protein 2 (M2), non-structural protein 1 (NS1), non-structural protein 2 or nuclear export protein (NS2 or NEP), Polymerase Acidic (PA), Polymerase Basic 1 (PB1), Polymerase Basic 2 (PB2) and PB1-F2. Each viral RNA (vRNA) segment forms a viral ribonucleoprotein (vRNP) complex together with NP and a polymerase complex (PB1, PB2, PA), which forms the fundamental unit for transcription and replication of the viral genome [1,10-18].

Influenza viral particles, via hemagglutinin glycoprotein, dock onto sialic acid sugar residues on the surfaces of host epithelial cells, where these particles gain entry through receptor mediated endocytosis [19]. Fusion of endosomal and viral membranes leads to release of viral RNA and core proteins, including accessory proteins and RNA-dependent RNA polymerase, into the cytoplasm $[\mathbf{2 0 , 2 1 ]}$. The vRNP complex is transported into the cell nucleus mediated by interaction of NP with importin- $\alpha[22,23]$. Once inside the nucleus, transcription and replication of viral genome is initiated by viral polymerases together with NP [24-27]. Newly synthesized viral proteins are either secreted through the Golgi apparatus onto the cell surface, for instance neuraminidase and hemagglutinin, or transported back into the nucleus to bind vRNA and form new viral genome particles [28].

Influenza type A viruses have constantly evolving nature and undergo two types of antigenic changes. One is a series of mutations due to the error prone RNA synthesis that occurs over time and causes a gradual evolution of the virus. This is 
Mayank et al. Virology Discovery 2014,

called antigenic "drift". The other kind of change is an abrupt change in the hemagglutinin and/or the neuraminidase proteins. This is called antigenic "shift". In such cases, new subtypes of virus suddenly emerge, which pose a continuing threat of pandemics. Hence it is imperative to develop novel interventional strategies to prevent their infection and spread $[1,29]$.

Influenza A virus on entering the host cell encounters numerous cellular proteins in various compartments of cells. Of these host proteins, many have been reported to play significant roles in key stages of influenza A virus life cycle. However much work needs to be done to decipher the host factors negatively or positively regulating the virus replication, the knowledge of which is essential for determining potential drug targets. Additionally, research aimed at elucidating the virus-host interactome can provide definite answers to viral pathogenicity and host determinants which make it species-specific.

One of the major developments in recent past is genome wide screening using RNAi technology, mass spectrometry etc. which has helped in identifying many proteins involved in virus entry, replication and budding [30,31]. In this review, we outline and discuss the analyses of such approaches pertaining to Influenza A virus. First, we summarize the recent genome-wide screens that have begun to reveal the depth of virus-host crosstalk. Next, we survey host factors identified to be interacting partners of viral proteins and their roles, either proposed or validated, in viral replication and life cycle.

\section{Review}

Genome-wide evidence of positive and restrictive factors regulating influenza a replication

Owed to the recent advancements in screening approaches based on powerful genome-wide molecular techniques such as yeast two hybrid screening for detecting protein protein interactions, mass spectrometric analysis, large scale knockdown using interfering RNA (siRNA and shRNA) etc., it is now clear that the interaction between Influenza and its host cell is much more complex and intricate than previously believed to be. Although many host molecules still remain elusive, emerging data indicate that their identification and characterization will provide new insights into the mechanisms by which viruses complete their life cycle. Some of the most significant genome wide screens aimed at unraveling virushost interactions have been highlighted below.

In the first of these screens, which was done by Hao et al., [32] (Table 1), the authors used Drosophila RNAi technology by modifying the influenza virus genetically so that it infects drosophila cells, wherein it expresses a reporter gene post infection. Since, drosophila has high degree of similarity in genome and pathways with vertebrates, it is a model system that can contribute to our understanding of influenza biology. Influenza does not normally infect insect cells, hence a genetically modified virus in which the vesicular stomatitis virus $G$ protein and a luciferase reporter replaced the viral $\mathrm{HA}$ and NA open reading frames was used. Also, the virus does not release virion particles into the medium. Therefore, this screen supported the middle stages of the influenza virus life cycle, such as release of viral vRNPs into host cytoplasm, entry of vRNPs into nucleus, viral mRNA synthesis in the nucleus, and export of mRNA into cytoplasm followed by protein synthesis. In this study an engineered influenza virus Flu-VSV-G-R.Luc was used with RNAi library against 13,071 genes (90\% of the Drosophila genome) and 110 genes were identified whose depletion in Drosophila cells significantly affected reporter gene expression. Of those 110 candidates, the human analogues of ATP6V0D1 (an ATPase), COX6A1 (a cytochrome c oxidase subunit), and NXF1 (a nuclear RNA export factor) were validated for their involvement in the replication of influenza A viruses in mammalian cells.

The genome wide screening in the mammalian cells using RNA interference approach was done by Brass et al., Konig et al., and Karlas et al., using which they identified numerous host genes necessary for viral replication. Brass et al., using dharmacon siRNA library targeted 17,877 genes in U2OS cells and screened for viral impairment by measuring surface expression of viral protein HA [33-35] (Table 1). They identified over 120 human host factors required by Influenza $A$ virus during its entire life cycle including entry, uncoating, vRNP trafficking, transcription, nuclear export, translation, and trafficking of HA to the surface. They further validated the role of IFITM3 (interferon inducible transmembrane protein 3) as an inhibitor of viral replication [36]. The screen by Konig et al., [37] (Table 1), was performed in A549 cells, targeting 19000 host proteins. Interestingly, they used a modified influenza A/WSN/33/virus in which the HA coding region is replaced by a Renilla luciferase reporter gene (WSN-Ren). Since the recombinant virus lacks $\mathrm{HA}$, the life cycle of the virus is incomplete, causing host factors involved in stages of virus assembly and budding to remain elusive. Using this luciferase-assay based RNAi screen Koing et al., identified 295 host factors. The screen performed by Karlas et al., [38] (Table 1) used a similar approach as Koing et al., They studied the entire viral life cycle, from viral attachment to budding, by assaying the viral infectivity using fluorescently labelled NP and luciferase activity in siRNA-treated, virus-infected A549 cells. This screen helped in identification of 287 human genes important for influenza virus replication.

Shapira et al., [39] (Table 1) combined the results of yeast two-hybrid analyses, genome-wide transcriptional gene expression profiling and an RNAi screen. They identified 1745 host factors which were further narrowed down to 616 by siRNA experiments. They also examined which cellular gene products were differentially expressed in primary human bronchial epithelial cells when exposed either to influenza virus or viral RNA. Mayer et al., in 2007 [40] (Table 1) used proteomics-based approach to identify cellular factors associated with reconstituted purified vRNPs. They used NP- 
Mayank al. Virology Discovery 2014,

http://www.hoajonline.com/journals/pdf/2052-6202-2-2.pdf

doi: $10.7243 / 2052-6202-2-2$

Table 1. A brief outline of different genome-wide approaches aimed at identifying cellular factors associated with influenza A virus replication.

\begin{tabular}{|c|c|c|c|c|c|}
\hline Group & Screening approach & Cell line used & Virus strain & Host Gene/Factors Targeted & No of Hits \\
\hline$[42]$ & Mass spectrometry & Vero & A/WSN/33 (H1N1) & $\begin{array}{l}\text { Host factors packaged within } \\
\text { virion particle }\end{array}$ & 36 \\
\hline$[40]$ & Mass spectrometry & HEK293T & A/WSN/33 (H1N1) & $\begin{array}{l}\text { Extracts from infected HEK293T } \\
\text { cells }\end{array}$ & 41 \\
\hline [43] & RNAi Screen & $\begin{array}{l}\text { HEK293T, } \\
\text { A549 }\end{array}$ & $\begin{array}{l}\text { Polymerases and vRNPs of A/WSN/33 } \\
\text { (H1N1); } \\
\text { A/VN/1203/04 (H5N1) }\end{array}$ & 31 & 18 \\
\hline$[32]$ & RNAi Screen & $\begin{array}{l}\text { Drosophila } \\
\text { cells }\end{array}$ & Recombinant virus A/WSN/33 (H1N1) & 13,071 & 110 \\
\hline$[34]$ & RNAi Screen & $\mathrm{U} 2 \mathrm{OS}$ & A/Puerto Rico/8/34 (H1N1) & 17,877 & 133 \\
\hline$[38]$ & RNAi Screen & A549 & A/WSN/33 (H1N1) & 22,843 & 227 \\
\hline [37] & RNAi Screen & A549 & Recombinant virus A/WSN/33 (H1N1) & 19,628 & 295 \\
\hline [39] & $\begin{array}{l}\text { Yeast } 2 \text { Hybrid, } \\
\text { microarry, RNAi screen }\end{array}$ & HBEC & $\begin{array}{l}\text { A/Puerto Rico/8/34 (H1N1); } \\
\text { A/Udorn/307/72 (H3N2) }\end{array}$ & 1,745 & 606 \\
\hline$[41]$ & RHGP & MDCK & A/Udorn/307/72 (H3N2) & $\begin{array}{l}\text { Host genes conferring resistance } \\
\text { to cells against influenza virus }\end{array}$ & 110 \\
\hline
\end{tabular}

Strep as a bait to purify vRNPs from the infected cells and identified co-purified cellular factors using mass spectrometry. Using the same technique they co-purified polymerase associated complexes. Using these approaches the group identified 41 proteins associated with viral vRNPs, of which they characterized the role of Nucleophosmin (NPM) as host factor necessary for viral polymerase activity. PARP-1 and importin- $\beta 3$ were two novel host proteins identified in the screen using viral polymerase as a bait. In an entirely novel effort Sui et al., [41] (Table 1) designed and used random homozygous gene perturbation (RHGP) to identify and validate the host targets that provide resistance to the host cell against influenza infection. This technique involves the use of RHGP library which consists of unique lentiviral-genetic element known as Gene search vector (GSV). GSV either knocks down the target gene (antisense integration) or produces its altered phenotype (sense integration). After the integration of RHGP library in the host cells, the cells are infected with an $\mathrm{MOI}$ which under normal condition causes cell death. Using this technique Sui et al., identified 110 host factors that render resistance to host cells against influenza virus.

Enveloped viruses like influenza have a capability to incorporate host intracellular and membrane proteins during viral packaging. There are a number of such host proteins known, which have been reported to be packaged in viral particles and also documented to interact with viral structural proteins. However the probable functions of such proteins remain unclear and further studies are required to explore their exact mechanistic roles and their potential candidature as anti-viral drug targets. In such an effort, Shaw et al., [42] (Table 1) for the first time studied host factors which are incorporated in the influenza virion particles. In this study, Shaw et al., utilized an approach based on mass spectroscopy to identify host cellular proteins incorporated in purified virion particle and got 36 hits. These include cytoskeletal proteins (actin, tubulin, cofilin), annexin family members (A1, A2, A4, A5 and $A 11$ ), two members of teraraspanin family (CD81 andCD9), CD5, cyclophilin A and other glycolytic enzymes.

In another study, Bortz et al., [43] (Table 1) used RNAi technology to assess host factors interacting specifically with viral ribonucleprotein complex (vRNP) and viral polymerases, in order to study their role in regulation of viral polymerases and host adaptation in $\mathrm{H} 5 \mathrm{~N} 1$ and $\mathrm{H} 1 \mathrm{~N} 1$ infected cells. As part of this approach, 31 host factors previously identified by Shapira et al., were silenced and viral polymerase activity was measured using minigenome reporter assay. This led to identification of 18 proteins including RNA binding proteins (DDX17, DDX5, NPM1 and hnRNP), cellular stress proteins (PARP1, Ku70/86, and DDB1) and molecular transport proteins (KPNA1, KPNA3, HSP90, HSP70, and RanBP5).

Owed to its well-established and frequently refined protocol and relatively inexpensive methodology, traditional Yeast 2 Hybrid $(\mathrm{Y} 2 \mathrm{H})$ has been widely exploited in flu research to screen almost entire cellular proteome including membrane proteins, subcellular compartmental proteins and transcription factors [44]. $\mathrm{Y} 2 \mathrm{H}$ is one of the few techniques which identifies direct protein-protein interactions, albeit providing relatively low number of hits in the screen. Therefore it is not surprising that a large number of host cellular factors have been identified as interacting partners of influenza viral proteins based on this technique. Hsp40, Clusterin, Karyopherin A, actinin-4 and actin are few examples of cellular interactors of viral NP identified using $\mathrm{Y} 2 \mathrm{H}$ [45-49]. Similarly, $\mathrm{M} 1$ has been reported to interact with Annexin A6 and Cyclophilin A [50,51]. CEACAM6 has been shown as a host interacting partner of $\mathrm{NA}$, the interaction playing a role in cell survival during viral 
Mayank et al. Virology Discovery 2014,

replication [52]. Recently NS1 and NS2 have been screened using $\mathrm{Y} 2 \mathrm{H}$ for a total of 79 host factors including AIMP2, SCRIB, CPSF4, PIK3R1, PIK3R2, MAPK9, CRK, STAU1, PRKRA, ADAR1, TARBP2 and ILF3 [53]. Hence Y2H based screens continue to contribute appreciably to the ever-building data on host factors involved in virus life cycle.

Next generation sequencing (NGS) represents a revolutionary development in the present era of sequencing technology. It is a new-age high-throughput DNA sequencing technique which has considerably influenced animal virology in the field of diagnostics and host virus interaction. Though it has been recently introduced, NGS has found extensive applications in metagenomics-based strategies for the discovery of novel viruses, whole viral genome sequencing, detection of viral genome variability, and the study of viral dynamics [54]. Particularly, in influenza virus research, the need for whole genome sequencing has stemmed from the sudden emergence of $\mathrm{H} 5 \mathrm{~N} 1$ subtype and $\mathrm{H} 1 \mathrm{~N} 1$ pandemic, which gives rise to the urgent need to understand the evolution, transmission and molecular epidemiology of these viruses [54-56]. Indeed, NGS, by making possible sequencing of many full genomes, has paved the way for better understanding of the emergence and transmission of influenza viruses [56]. In line with this, Huang et al., [57] used NGS technology to generate sequence of the duck genome and performed deep transcriptome analyses to characterize gene expression profiles and to identify host genes responsive to avian influenza virus. A comparison of gene expression profile was carried out between ducks infected with $\mathrm{DK} / 49$ and $\mathrm{GS} / 65$ subtypes of $\mathrm{H} 5 \mathrm{~N} 1$ virus and control ducks. This analysis revealed down-regulation of a number of host immune-related genes including growth factors (e.g. BMP1-5, EGF, FGF9 etc.), chemokines (CXCL12, CXCL14 etc.) TNFSF11 and IL17 in infected birds when compared to controls. By contrast, all five interferon genes (IFNA, IFNE, IFNG, IFNK, IL28A), thirteen growth factors (BMP8, FGF8, EFNA1 etc.), CC chemokine genes (CCL4L2, CCL5, CCL6, CCL17 etc.), ten interleukin or interleukin receptor genes (IL1, IL6, IL10, IL13 etc.) and RNA helicases (DDX58, IFITM3 and IFIT1-IFIT3) were found to be up-regulated. However, only this study has extensively investigated the host gene expression profile in response to infection and much work still needs to be done to utilize next generation sequencing platforms to unveil multiple layers of host-virus interactome and extend our current knowledge of the host genes playing a role in influenza infection [57].

In the screens described above, around 1500 genes were identified as capable of assisting Influenza A replication. It is interesting to note that each of these screens has identified a distinct and previously uncharacterized set of genes/factors, covering only a small percentage of the whole genome, with only a small overlap among different screens. Hence much work still needs to be done to formulate a more comprehensive and general strategy utilizing these genome-wide screens in order to unbiasedly dissect the yet unexplored host circuitry involved in influenza viral life cycle.

\section{Known cellular factors involved In the influenza a life} cycle

Besides the genome-wide screens described above, there have been many studies, as described below, focusing on particular stages of the viral life cycle and the cellular processes and individual cellular factors identified as being associated.

\section{Viral entry and uncoating}

The viral replication cycle is initiated by binding of its major surface protein, hemagglutinin, to sialic acids that are omnipresent on the glycolipids and glycoproteins exposed on the surfaces of cells and its subsequent internalization. The first protein shown to be required for endocytosis was clathrin, which mediates the primary route of endocytic internalization into cells with the requirement for the adapter protein epsin 1. However, non-coated vesicles are also observed, due to either release of clathrin or to the presence of non-clathrin-coated pathways. Several cellular proteins such as GTPases Rab5 and Rab7/protein kinase C b II (PKCbll), Rab10, interferon-inducible transmembrane proteins (IFITM1, IFITM3, IFITM3) have been identified and validated for their involvement in virus entry and endosomal movement inside the cell $[32,34]$. Studies have also identified subunits of coatomer (COPI) vesicular transport complex, ARCN1, COPG, COPA, COPB2, which have functions in retrograde transport from Golgi-ER [32,34,37-39].

Virus disassembly or uncoating occurs in the acidic environment of late endosomal vesicles, which is crucial for the uncoating process in two ways. First, low $\mathrm{pH}$ triggers a conformational change in the $\mathrm{HA}$, exposing a fusion peptide that mediates the merging of the viral envelope with the endosomal membrane, thus opening a pore through which the viral vRNPs are released into the host cell cytoplasm [58]. Second, hydrogen ions from the endosome are pumped into the virus particle via the $\mathrm{M} 2$ ion channel. Acidification further facitilates dissociation of the viral nucleocapsids from the M1 matrix protein [59]. The vRNPs are subsequently released into the cytoplasm and imported into the nucleus. Several subunits of V-type ATPase complex are identified to have functions in both acidification and fusion of the cellular compartment of endosomes, knockdown of which causes inhibition of viral replication [32,34,37-39].

\section{Transport of vRNPs across nuclear membrane}

In order to accomplish nuclear import the viral genome utilizes cellular transport machinery. The transport of vRNPs in the nucleus is likely mediated by at least two nuclear localizing signals (NLS1 and NLS2) present on NP [60], facilitating the import of vRNPs through nuclear pore complex (NPC). Also cellular factors importin $a 1, a 3$ and a5, RanBP3, RanBP5 are reported to bind NP, PB2, PB1, and PA [61-63] which are involved in this process. In the large scale screening approaches two nuclear pore complex subunits Nup98 and Nup153 have been identified [32,34,37-39]. All these factors are utilized by viral proteins to import newly formed vRNPs into the nucleus. 


\section{Viral RNA and protein synthesis}

The replication and transcription of viral RNA takes place in infected nucleus by trimeric viral RNA dependent RNA polymerase. The vRNPs transported into the nucleus undergo viral mRNA synthesis and are then replicated via complementary RNA (cRNA). PB1 has the RNA dependent RNA polymerase activity, PA is involved in cap-snatching process from the host $m R N A$ via its endonuclease activity, and PB2 contains the cap binding domain. The viral nucleoprotein NP which associates with the viral RNAs is a fourth essential cofactor of the viral replicative complex [24-26]. Influenza virus RNAs carry at their $5^{\prime}$ - and $3^{\prime}$ - ends conserved nucleotide sequences of 13 and 12 bases, respectively. These sequences are in part complementary to each other which leads to formation of a partially doublestranded promoter structure. The viral RNA dependent RNA polymerase binds to and initiates RNA synthesis at these promoter structures of the viral RNA segments. A number of cellular factors have been identified which play role in RNA synthesis including BAT1/UAP56, Tat-SF1, MCM complex, DNA dependent Polymerase II and Hsp90 [64-69]. Cellular factor BAT1/UAP56, an mRNA splicing factor belonging to the DEADbox family of RNA-dependent ATPases, helps in the formation of NP-RNA complex via its interaction with NP, thus enhancing viral RNA synthesis. NP-RNP complex formation is facilitated by Tat-SF1, which acts as a molecular chaperone for NP. Viral RNA synthesis is then catalyzed by viral polymerases. Cellular factor Hsp90 acts as a molecular chaperone of polymerase subunits, and is involved in viral RNA polymerases and nuclear transport prior to the formation of mature ternary polymerase complex. MCM complex is also known to interact with RNP complex through PA. MCM promotes the association between the nascent CRNA and viral polymerases, thus increasing the efficiency of viral replication by stabilizing the polymerase complexes. It is also reported that the viral RNA-dependent RNA polymerase interacts with the serine- 5 phosphorylated carboxy-terminal domain (CTD) of the largest subunit of RNA polymerase II (Pol II) and plays a role in the recruitment and stimulation of capping enzyme to snatch host mRNA cap, which is required as primer for the initiation of viral mRNA synthesis. It is worth noting that a number of factors engaged in host $m R N A$ splicing have been identified in many screening studies for unraveling host factors involved in influenza virus life cycle. Some of these factors include, NXF1 involved in export of host spliced mRNA, PTBP1, SF3B1, SF3A1, p14, NHP2L1, SNRP70 $[34,38,39]$. This indicates the importance and invoIvement of host mRNA splicing in viral replication. The virus uses the host cell's splicing machinery for its own purpose and at the same time prevents the host cell from using it for processing the host cell mRNAs. For example, NS1 binds to U6 small nuclear RNAs (snRNAs) and other splicing components [70], causing them to re-localize to the nucleus of infected cells. NS1 has also been shown to interact with a novel protein called NS1 binding protein (NS1-BP), the interaction causing it to re-localize to the nucleus in infected cells. The function of NS1-BP is unknown, although it is predicted to be involved in splicing given its co-localization with SC35, a spliceosome assembly factor [71].

Influenza viral protein translation relies upon the interactions of trans-acting factors with both ribosomal RNAs and cisacting determinants in the mRNA. Influenza virus protein synthesis is a cap-dependent process mediated by highly conserved sequences contained in the 5 'UTRs of the viral mRNAs. Although the influenza virus 5'UTRs are predicted to contain little secondary structure, they result in profound stimulatory effects on viral protein synthesis in infected cells, while substantially inhibiting host cell protein synthesis [64]. GRSF-1, a member of the RNP superfamily of RNA binding proteins, interacts with viral $5^{\prime}$ UTR and is a critical determinant in the selective translation of viral mRNA [72]. P58IPK, the cellular inhibitor of PKR, regulates influenza virus $m R N A$ translation by interfering with PKR's ability to phosphorylate elF $2 \alpha$, thus inhibiting host mRNA traslation and promoting viral protein synthesis [73].

\section{Export of vRNPs from the nucleus}

The newly synthesized vRNPs are exported out from the nucleus via the CRM1 dependent pathway through the nuclear pore complex. NP has been shown to interact with CRM1 directly, although no GTP hydrolysis activity could be detected [74]. $\mathrm{M} 1$ also has a critical role in vRNP export, M1 interacts directly with the vRNPs through the C-terminal end of the protein. It has been shown that the $\mathrm{N}$-terminal portion of $\mathrm{M} 1$ can bind to NEP (Nuclear export protein), thus masking the NLS [75]. NEP has also been shown to bind to CRM1 with the accompanying GTP hydrolysis that normally occurs in CRM1-dependent export pathway. Therefore, it is hypothesised that M1 binds to the negative sense vRNPs, as well as to NEP. In turn, NEP binds to CRM1, and through this "daisy-chain" complex, the vRNPs are exported out of the nucleus. In another study a direct interaction between $\mathrm{M} 1$ and heat shock conjugate $\mathrm{Hsc} 70$ has been reported and strongly implicated in nuclear export of vRNP-M1 complex [76].

\section{Viral assembly and budding}

After the exit of vRNPs from the nucleus viral particles are formed, which later bud out from the cell. Since influenza is an enveloped virus, it uses the host cell's plasma membrane to form the viral particles. All viral components including vRNPs, Matrix protein $\mathrm{M} 1$, and envelope proteins $\mathrm{HA}, \mathrm{NA}$ and $\mathrm{M} 2$, are transported to and assembled at the apical plasma membrane [28]. NP and M1 have been reported to be associated with host cytoskeleton protein such as actin and actinin- 4 which indicates a possible role in VRNP translocation to the budding site $[48,49,77]$. In the screening carried out by Brass et al., depletion of COPI subunits led to reduced expression of $\mathrm{HA}$ on the plasma membrane of the host cell, thus indicating involvement of these proteins in transport of viral glycoproteins (NA and $\mathrm{HA}$ ) to the cell surface. It has been reported that viral 
Mayank et al. Virology Discovery 2014,

http://www.hoajonline.com/journals/pdf/2052-6202-2-2.pdf

doi: $10.7243 / 2052-6202-2-2$

M2 plays an important part in viral packaging. Viruses that had M2 tail deleted or partially mutated produce elongated particles. M1, which is present underneath the lipid bilayer, is important in the final step of closing and budding off of the viral particle [78]. However, not many host factors, except actin and Rab11 [79] have been identified till date which take part in viral budding.

\section{Conclusion}

Infection with influenza virus causes a contagious disease of respiratory tract which spreads around in seasonal epidemics and sometimes global pandemics. The circulation of highly pathogenic influenza virus causes severe clinical manifestations with high rate of mortality. Effective preventive measures currently available against influenza include vaccination and administration of drugs therapeutically. Since the influenza virus has high rate of mutation attributed to processes of antigenic shift and drift, it can evade the effectiveness of annual vaccination. Further, the conventional use of antivirals has limitations arising from the development of resistant strains and a lack of broad-spectrum application. Recent studies strongly suggest that constantly evolving viral genome induces resistance against current anti-influenza drug regimens comprising of newly developed drugs such as oseltamivir (Tamiflu), zanamivir, amantadine etc. Hence the need of the hour is to develop novel therapeutic strategies aimed at mitigating the impact of seasonal influenza, increasing the preparedness for upcoming influenza epidemics as well as combating the problem of resistance. Evidence is building which strongly suggests that one such approach to combat viral infection is to target host factors that are essential for viral life cycle and pathogenesis, as they are much less likely to undergo mutational changes. Hence genome-wide screening disposes to us a great tool that can help identify host molecular factors affecting viral replication, which when targeted can confer tolerance to influenza infection.

Systematic genome-wide screening approach offers a powerful tool to examine the entire host genome in order to identify cellular factors critical for infection. Although siRNA based genome wide screening has come a long way, it has several limitations such as off-target effects/partial knockdown leading to generation of false positives/negatives, cytotoxicity of siRNA libraries etc. Nevertheless efforts such as using additional siRNA sequences to minimize the disclosure of false positive cellular factors, are underway to further refine this technique and make it more failsafe. Large scale screens with improved stringency and dedicated to a specific process such as entry, replication, transcription or assembly can prove to be very beneficial in elucidation of regulatory networks specific to a particular stage of viral life cycle. The data mined using various genome-wide techniques can be collated and compiled using systems biology approach to predict pathways involved in viral infection. Additionally, further analysis of various genes and factors identified using genome wide screening is required to unravel new pathways and mechanisms employed by the virus, thus not only enhancing our current understanding of viral life cycle but also developing novel interventional strategies to combat future epidemics and pandemics.

\section{Competing interests}

The authors declare that they have no competing interests.

Authors' contributions

\begin{tabular}{|l|c|c|c|c|}
\hline Authors' contributions & AKM & SS & RKD & SKL \\
\hline Research concept and design & -- & -- & $\checkmark$ & $\checkmark$ \\
\hline Collection and/or assembly of data & $\checkmark$ & $\checkmark$ & -- & -- \\
\hline Data analysis and interpretation & $\checkmark$ & $\checkmark$ & $\checkmark$ & $\checkmark$ \\
\hline Writing the article & $\checkmark$ & $\checkmark$ & -- & -- \\
\hline Critical revision of the article & $\checkmark$ & $\checkmark$ & $\checkmark$ & $\checkmark$ \\
\hline Final approval of article & -- & -- & -- & $\checkmark$ \\
\hline
\end{tabular}

Acknowledgement

We would like to thank Dr. Vijaya Pandey for critical reviewing of the manuscript and for useful comments. This study was supported by internal funds from ICGEB, a research grant from the Department of Biotechnology, New Delhi. AKM and SS were supported by a fellowship from Indian Medical Research Council, New Delhi, India.

\section{Publication history}

Editors: Weifeng Shi, Guangzhou Institute of Advanced Technology, China.

Upal Roy, Florida International University, USA.

EIC: Preet M. Chaudhary, University of Southern California Keck School of Medicine, USA.

Received: 09-Apr-2014 Final Revised: 09-May-2014

Accepted: 23-May-2014 Published: 13-Jun-2014

\section{References}

1. Webster RG, Bean WJ, Gorman OT, Chambers TM and Kawaoka Y. Evolution and ecology of influenza A viruses. Microbiol Rev. 1992; 56:152-79. | Article | PubMed Abstract | PubMed Full Text

2. Reid AH, Fanning TG, Hultin JV and Taubenberger JK. Origin and evolution of the 1918 "Spanish" influenza virus hemagglutinin gene. Proc Natl Acad Sci U S A. 1999; 96:1651-6. | Article | PubMed Abstract | PubMed Full Text

3. Gibbs MJ, Armstrong JS and Gibbs AJ. Recombination in the hemagglutinin gene of the 1918 "Spanish flu". Science. 2001; 293:18425. | Article | PubMed

4. Scholtissek C, Rohde W, Von Hoyningen V and Rott R. On the origin of the human influenza virus subtypes H2N2 and H3N2. Virology. 1978; 87:13-20. | PubMed

5. Webster RG. Influenza virus: transmission between species and relevance to emergence of the next human pandemic. Arch Virol Suppl. 1997; 13:105-13. | Article | PubMed

6. Pensaert M, Ottis K, Vandeputte J, Kaplan MM and Bachmann PA. Evidence for the natural transmission of influenza A virus from wild ducts to swine and its potential importance for man. Bull World Health Organ. 1981; 59:75-8. | PubMed Abstract | PubMed Full Text

7. Air GM, Laver WG and Webster RG. Antigenic variation in influenza viruses. Contrib Microbiol Immunol. 1987; 8:20-59. | PubMed

8. Horne RW, Waterson AP, Wildy P and Farnham AE. The structure and composition of the myxoviruses. I. Electron microscope studies of the structure of myxovirus particles by negative staining techniques. Virology. 1960; 11:79-98. I PubMed

9. Hoyle L, Horne RW and Waterson AP. The structure and composition of the myxoviruses. II. Components released from the influenza virus 
Mayank al. Virology Discovery 2014,

http://www.hoajonline.com/journals/pdf/2052-6202-2-2.pdf

doi: $10.7243 / 2052-6202-2-2$

particle by ether. Virology. 1961; 13:448-59. | Article | PubMed

10. Palese $P$ and Schulman JL. Mapping of the influenza virus genome: identification of the hemagglutinin and the neuraminidase genes. Proc Natl Acad Sci U S A. 1976; 73:2142-6. | Article | PubMed Abstract | PubMed Full Text

11. Etkind PR, Buchhagen DL, Herz C, Broni BB and Krug RM. The segments of influenza viral mRNA. J Virol. 1977; 22:346-52. | Article | PubMed Abstract | PubMed Full Text

12. Das K, Aramini JM, Ma LC, Krug RM and Arnold E. Structures of influenza A proteins and insights into antiviral drug targets. Nat Struct Mol Biol. 2010; 17:530-8. | Article | PubMed Abstract | PubMed Full Text

13. Liu Y, Lou Z, Bartlam M and Rao Z. Structure-function studies of the influenza virus RNA polymerase PA subunit. Sci China C Life Sci. 2009; 52:450-8. | Article | PubMed

14. Hale BG, Randall RE, Ortin J and Jackson D. The multifunctional NS1 protein of influenza A viruses. J Gen Virol. 2008; 89:2359-76. | Article | PubMed

15. Zheng $W$ and Tao YJ. Structure and assembly of the influenza $A$ virus ribonucleoprotein complex. FEBS Lett. 2013; 587:1206-14. | Article | PubMed

16. Pielak RM and Chou JJ. Influenza M2 proton channels. Biochim Biophys Acta. 2011; 1808:522-9. | Article | PubMed Abstract | PubMed Full Text

17. Payungporn S, Panjaworayan N, Makkoch J and Poovorawan Y. Molecular characteristics of the human pandemic influenza A virus (H1N1). Acta Virol. 2010; 54:155-63. | Article | PubMed

18. Hutchinson EC, von Kirchbach JC, Gog JR and Digard P. Genome packaging in influenza A virus. J Gen Virol. 2010; 91:313-28. | Article | PubMed

19. Edinger TO, Pohl MO and Stertz S. Entry of influenza A virus: host factors and antiviral targets. J Gen Virol. 2014; 95:263-77. | Article | PubMed

20. Leiding T, Wang J, Martinsson J, DeGrado WF and Arskold SP. Proton and cation transport activity of the M2 proton channel from influenza $A$ virus. Proc Natl Acad Sci U S A. 2010; 107:15409-14. | Article | PubMed Abstract | PubMed Full Text

21. Bukrinskaya AG, Vorkunova NK, Kornilayeva GV, Narmanbetova RA and Vorkunova GK. Influenza virus uncoating in infected cells and effect of rimantadine. J Gen Virol. 1982; 60:49-59. | Article | PubMed

22. Hutchinson EC and Fodor E. Nuclear import of the influenza $A$ virus transcriptional machinery. Vaccine. 2012; 30:7353-8. | Article | PubMed

23. Huet S, Avilov SV, Ferbitz L, Daigle N, Cusack S and Ellenberg J. Nuclear import and assembly of influenza A virus RNA polymerase studied in live cells by fluorescence cross-correlation spectroscopy. J Virol. 2010; 84:1254-64. | Article | PubMed Abstract | PubMed Full Text

24. Fodor $E$. The RNA polymerase of influenza a virus: mechanisms of viral transcription and replication. Acta Virol. 2013; 57:113-22. | Article | PubMed

25. Moeller A, Kirchdoerfer RN, Potter CS, Carragher B and Wilson IA. Organization of the influenza virus replication machinery. Science. 2012; 338:1631-4. | Article | PubMed Abstract | PubMed Full Text

26. Chenavas S, Crepin T, Delmas B, Ruigrok RW and Slama-Schwok A. Influenza virus nucleoprotein: structure, RNA binding, oligomerization and antiviral drug target. Future Microbiol. 2013; 8:1537-45. | Article | PubMed

27. Steinhauer DA and Skehel JJ. Genetics of influenza viruses. Annu Rev Genet. 2002; 36:305-32. | Article | PubMed

28. Rossman JS and Lamb RA. Influenza virus assembly and budding. Virology. 2011; 411:229-36. | Article | PubMed Abstract | PubMed Full Text

29. Hsieh YC, Wu TZ, Liu DP, Shao PL, Chang LY, Lu CY, Lee CY, Huang FY and Huang LM. Influenza pandemics: past, present and future. J Formos Med Assoc. 2006; 105:1-6. | Article | PubMed

30. Cardoza JD, Parikh JR, Ficarro SB and Marto JA. Mass spectrometrybased proteomics: qualitative identification to activity-based protein profiling. Wiley Interdiscip Rev Syst Biol Med. 2012; 4:141-62. | Article | $\underline{\text { PubMed Abstract } \mid \text { PubMed Full Text }}$
31. Mohr SE and Perrimon N. RNAi screening: new approaches, understandings, and organisms. Wiley Interdiscip Rev RNA. 2012; 3:14558. | Article | PubMed Abstract | PubMed Full Text

32. Hao L, Sakurai A, Watanabe T, Sorensen E, Nidom CA, Newton MA, Ahlquist $P$ and Kawaoka Y. Drosophila RNAi screen identifies host genes important for influenza virus replication. Nature. 2008; 454:890-3. | Article | PubMed Abstract | PubMed Full Text

33. Wyers F, Richard-Molard C, Blondel D and Dezelee S. Vesicular stomatitis virus growth in Drosophila melanogaster cells: $G$ protein deficiency. $J$ Virol. 1980; 33:411-22. | Article | PubMed Abstract | PubMed Full Text

34. Brass AL, Huang IC, Benita Y, John SP, Krishnan MN, Feeley EM, Ryan BJ, Weyer JL, van der Weyden L, Fikrig E, Adams DJ, Xavier RJ, Farzan M and Elledge SJ. The IFITM proteins mediate cellular resistance to influenza $A$ H1N1 virus, West Nile virus, and dengue virus. Cell. 2009; 139:1243-54. | Article | PubMed Abstract | PubMed Full Text

35. Chin CR and Brass AL. A genome wide RNA interference screening method to identify host factors that modulate influenza $A$ virus replication. Methods. 2013; 59:217-24. | Article | PubMed

36. Everitt AR, Clare S, Pertel T, John SP, Wash RS, Smith SE, Chin CR, Feeley EM, Sims JS, Adams DJ, Wise HM, Kane L, Goulding D, Digard P, Anttila V, Baillie JK, Walsh TS, Hume DA, Palotie A, Xue Y, Colonna V, Tyler-Smith C, Dunning J, Gordon SB, Smyth RL, Openshaw PJ, Dougan G, Brass AL and Kellam P. IFITM3 restricts the morbidity and mortality associated with influenza. Nature. 2012; 484:519-23. | Article | PubMed Abstract | PubMed Full Text

37. Konig R, Stertz S, Zhou Y, Inoue A, Hoffmann HH, Bhattacharyya S, Alamares JG, Tscherne DM, Ortigoza MB, Liang Y, Gao Q, Andrews SE, Bandyopadhyay S, De Jesus P, Tu BP, Pache L, Shih C, Orth A, Bonamy G, Miraglia L, Ideker T, Garcia-Sastre A, Young JA, Palese P, Shaw ML and Chanda SK. Human host factors required for influenza virus replication. Nature. 2010; 463:813-7. | Article | PubMed Abstract | PubMed Full Text

38. Karlas A, Machuy N, Shin Y, Pleissner KP, Artarini A, Heuer D, Becker D, Khalil H, Ogilvie LA, Hess S, Maurer AP, Muller E, Wolff T, Rudel T and Meyer TF. Genome-wide RNAi screen identifies human host factors crucial for influenza virus replication. Nature. 2010; 463:818-22. | Article | PubMed

39. Shapira SD, Gat-Viks I, Shum BO, Dricot A, de Grace MM, Wu L, Gupta PB, Hao T, Silver SJ, Root DE, Hill DE, Regev A and Hacohen N. A physical and regulatory map of host-influenza interactions reveals pathways in H1N1 infection. Cell. 2009; 139:1255-67. | Article | PubMed Abstract | PubMed Full Text

40. Mayer D, Molawi K, Martinez-Sobrido L, Ghanem A, Thomas S, Baginsky S, Grossmann J, Garcia-Sastre A and Schwemmle M. Identification of cellular interaction partners of the influenza virus ribonucleoprotein complex and polymerase complex using proteomic-based approaches J Proteome Res. 2007; 6:672-82. | Article | PubMed Abstract | PubMed Full Text

41. Sui B, Bamba D, Weng K, Ung H, Chang S, Van Dyke J, Goldblatt M, Duan R, Kinch MS and Li WB. The use of Random Homozygous Gene Perturbation to identify novel host-oriented targets for influenza. Virology. 2009; 387:473-81. | Article | PubMed Abstract | PubMed Full Text

42. Shaw ML, Stone KL, Colangelo CM, Gulcicek EE and Palese P. Cellular proteins in influenza virus particles. PLoS Pathog. 2008; 4:e1000085. | Article | PubMed Abstract | PubMed Full Text

43. Bortz E, Westera L, Maamary J, Steel J, Albrecht RA, Manicassamy B, Chase G, Martinez-Sobrido L, Schwemmle M and Garcia-Sastre A. Hostand strain-specific regulation of influenza virus polymerase activity by interacting cellular proteins. MBio. 2011; 2:151-11. | Article | PubMed Abstract I PubMed Full Text

44. Bruckner A, Polge C, Lentze N, Auerbach D and Schlattner U. Yeast twohybrid, a powerful tool for systems biology. Int J Mol Sci. 2009; 10:276388. | Article | PubMed Abstract | PubMed Full Text

45. Sharma K, Tripathi S, Ranjan P, Kumar P, Garten R, Deyde V, Katz JM, Cox NJ, Lal RB, Sambhara S and Lal SK. Influenza A virus nucleoprotein exploits Hsp40 to inhibit PKR activation. PLoS One. 2011; 6:e20215. | Article | PubMed Abstract | PubMed Full Text 
Mayank et al. Virology Discovery 2014,

46. Tripathi S, Batra J, Cao W, Sharma K, Patel JR, Ranjan P, Kumar A, Katz JM, Cox NJ, Lal RB, Sambhara S and Lal SK. Influenza A virus nucleoprotein induces apoptosis in human airway epithelial cells: implications of a novel interaction between nucleoprotein and host protein Clusterin. Cell Death Dis. 2013; 4:e562. | Article | PubMed Abstract | PubMed Full $\underline{\text { Text }}$

47. O'Neill RE, Jaskunas R, Blobel G, Palese P and Moroianu J. Nuclear import of influenza virus RNA can be mediated by viral nucleoprotein and transport factors required for protein import. J Biol Chem. 1995; 270:22701-4. | Article | PubMed

48. Digard P, Elton D, Bishop K, Medcalf E, Weeds A and Pope B. Modulation of nuclear localization of the influenza virus nucleoprotein through interaction with actin filaments. J Virol. 1999; 73:2222-31. | Article | PubMed Abstract | PubMed Full Text

49. Sharma S, Mayank AK, Nailwal H, Tripathi S, Patel JR, Bowzard JB, Gaur P, Donis RO, Katz JM, Cox NJ, Lal RB, Farooqi H, Sambhara S and Lal SK. Influenza A Viral Nucleoprotein Interacts with Cytoskeleton Scaffolding Protein alpha-actinin-4 for Viral Replication. FEBS J. 2014. | Article | PubMed

50. Liu X, Sun L, Yu M, Wang Z, Xu C, Xue Q, Zhang K, Ye X, Kitamura Y and Liu W. Cyclophilin A interacts with influenza $A$ virus $M 1$ protein and impairs the early stage of the viral replication. Cell Microbiol. 2009; 11:730-41. | Article | PubMed

51. Ma H, Kien F, Maniere M, Zhang Y, Lagarde N, Tse KS, Poon LL and Nal B. Human annexin A6 interacts with influenza a virus protein $\mathrm{M} 2$ and negatively modulates infection. J Virol. 2012; 86:1789-801. | Article | PubMed Abstract | PubMed Full Text

52. Gaur P, Ranjan P, Sharma S, Patel JR, Bowzard JB, Rahman SK, Kumari R, Gangappa S, Katz JM, Cox NJ, Lal RB, Sambhara S and Lal SK. Influenza A virus neuraminidase protein enhances cell survival through interaction with carcinoembryonic antigen-related cell adhesion molecule 6 (CEACAM6) protein. J Biol Chem. 2012; 287:15109-17. | Article | PubMed Abstract I PubMed Full Text

53. de Chassey B, Aublin-Gex A, Ruggieri A, Meyniel-Schicklin L, Pradezynski F, Davoust N, Chantier T, Tafforeau L, Mangeot PE, Ciancia C, PerrinCocon L, Bartenschlager R, Andre P and Lotteau V. The interactomes of influenza virus NS1 and NS2 proteins identify new host factors and provide insights for ADAR1 playing a supportive role in virus replication. PLoS Pathog. 2013; 9:e1003440. | Article | PubMed Abstract | PubMed Full Text

54. Capobianchi MR, Giombini E and Rozera G. Next-generation sequencing technology in clinical virology. Clin Microbiol Infect. 2013; 19:15-22. | Article | PubMed

55. Ghedin E, Fitch A, Boyne A, Griesemer S, DePasse J, Bera J, Zhang X, Halpin RA, Smit M, Jennings L, St George K, Holmes EC and Spiro DJ. Mixed infection and the genesis of influenza virus diversity. J Virol. 2009; 83:8832-41. | Article | PubMed Abstract | PubMed Full Text

56. Radford AD, Chapman D, Dixon L, Chantrey J, Darby AC and Hall N. Application of next-generation sequencing technologies in virology. $J$ Gen Virol. 2012; 93:1853-68. | Article | PubMed Abstract | PubMed Full $\underline{\text { Text }}$

57. Huang Y, Li Y, Burt DW, Chen H, Zhang Y, Qian W, Kim H, Gan S, Zhao Y, Li J, Yi K, Feng H, Zhu P, Li B, Liu Q, Fairley S, Magor KE, Du Z, Hu X, Goodman L, Tafer H, Vignal A, Lee T, Kim KW, Sheng Z, An Y, Searle S, Herrero J, Groenen MA, Crooijmans RP, Faraut T, Cai Q, Webster RG, Aldridge JR, Warren WC, Bartschat S, Kehr S, Marz M, Stadler PF, Smith J, Kraus RH, Ren L, Fei J, Morisson M, Kaiser P, Griffin DK, Rao M, Pitel F, Wang J and $\mathrm{Li}$. The duck genome and transcriptome provide insight into an avian influenza virus reservoir species. Nat Genet. 2013; 45:776-83. | Article | PubMed Abstract | PubMed Full Text

58. Lanzrein M, Schlegel $A$ and Kempf C. Entry and uncoating of enveloped viruses. Biochem J. 1994; 302:313-20. | Pdf | PubMed Abstract | PubMed Full Text

59. Cady SD, Luo W, Hu F and Hong M. Structure and function of the influenza A M2 proton channel. Biochemistry. 2009; 48:7356-64. | Article | PubMed Abstract | PubMed Full Text

60. Cros JF, Garcia-Sastre A and Palese P. An unconventional NLS is critical for the nuclear import of the influenza $A$ virus nucleoprotein and ribonucleoprotein. Traffic. 2005; 6:205-13. | Article | PubMed

61. Melen K, Fagerlund R, Franke J, Kohler M, Kinnunen L and Julkunen I. Importin alpha nuclear localization signal binding sites for STAT1, STAT2, and influenza A virus nucleoprotein. J Biol Chem. 2003; 278:28193-200. | Article | PubMed

62. Predicala $R$ and Zhou $Y$. The role of Ran-binding protein 3 during influenza A virus replication. J Gen Virol. 2013; 94:977-84. | Article | PubMed

63. Hutchinson EC, Orr OE, Man Liu S, Engelhardt OG and Fodor E. Characterization of the interaction between the influenza $A$ virus polymerase subunit PB1 and the host nuclear import factor Ran-binding protein 5. J Gen Virol. 2011; 92:1859-69. | Article | PubMed

64. Portela $A$ and Digard $P$. The influenza virus nucleoprotein: a multifunctional RNA-binding protein pivotal to virus replication. J Gen Virol. 2002; 83:723-34. | Article | PubMed

65. Wisskirchen C, Ludersdorfer TH, Muller DA, Moritz E and Pavlovic J. The cellular RNA helicase UAP56 is required for prevention of doublestranded RNA formation during influenza A virus infection. J Virol. 2011; 85:8646-55. | Article | PubMed Abstract | PubMed Full Text

66. Naito T, Kiyasu Y, Sugiyama K, Kimura A, Nakano R, Matsukage A and Nagata K. An influenza virus replicon system in yeast identified Tat-SF1 as a stimulatory host factor for viral RNA synthesis. Proc Natl Acad Sci U S A. 2007; 104:18235-40. | Article | PubMed Abstract | PubMed Full Text

67. Chan AY, Vreede FT, Smith M, Engelhardt OG and Fodor E. Influenza virus inhibits RNA polymerase II elongation. Virology. 2006; 351:210-7. | Article | PubMed

68. Kawaguchi $A$ and Nagata K. De novo replication of the influenza virus RNA genome is regulated by DNA replicative helicase, MCM. EMBO J. 2007; 26:4566-75. | Article | PubMed Abstract | PubMed Full Text

69. Naito T, Momose F, Kawaguchi A and Nagata K. Involvement of Hsp90 in assembly and nuclear import of influenza virus RNA polymerase subunits. J Virol. 2007; 81:1339-49. | Article | PubMed Abstract | PubMed Full Text

70. Qiu Y, Nemeroff $M$ and Krug RM. The influenza virus NS1 protein binds to a specific region in human U6 snRNA and inhibits U6-U2 and U6-U4 snRNA interactions during splicing. RNA. 1995; 1:304-16. | Article | PubMed Abstract | PubMed Full Text

71. Wolff T, O'Neill RE and Palese P. NS1-Binding protein (NS1-BP): a novel human protein that interacts with the influenza $A$ virus nonstructural NS1 protein is relocalized in the nuclei of infected cells. J Virol. 1998; 72:7170-80. | Article | PubMed Abstract | PubMed Full Text

72. Park YW, Wilusz J and Katze MG. Regulation of eukaryotic protein synthesis: selective influenza viral mRNA translation is mediated by the cellular RNA-binding protein GRSF-1. Proc Natl Acad Sci U S A. 1999; 96:6694-9. | Article | PubMed Abstract | PubMed Full Text

73. Goodman AG, Smith JA, Balachandran S, Perwitasari O, Proll SC, Thomas MJ, Korth MJ, Barber GN, Schiff LA and Katze MG. The cellular protein P58IPK regulates influenza virus mRNA translation and replication through a PKR-mediated mechanism. J Virol. 2007; 81:2221-30. | Article | PubMed Abstract | PubMed Full Text

74. Elton D, Simpson-Holley M, Archer K, Medcalf L, Hallam R, McCauley J and Digard $P$. Interaction of the influenza virus nucleoprotein with the cellular CRM1-mediated nuclear export pathway. J Virol. 2001; 75:40819. | Article | PubMed Abstract | PubMed Full Text

75. Shimizu T, Takizawa N, Watanabe K, Nagata K and Kobayashi N. Crucial role of the influenza virus NS2 (NEP) C-terminal domain in M1 binding and nuclear export of vRNP. FEBS Lett. 2011; 585:41-6. | Article | PubMed

76. Watanabe K, Takizawa N, Noda S, Tsukahara F, Maru Y and Kobayashi $\mathrm{N}$. Hsc70 regulates the nuclear export but not the import of influenza viral RNP: A possible target for the development of anti-influenza virus drugs. Drug Discov Ther. 2008; 2:77-84. | Article | PubMed

77. Avalos RT, Yu Z and Nayak DP. Association of influenza virus NP and M1 proteins with cellular cytoskeletal elements in influenza virus-infected cells. J Virol. 1997; 71:2947-58. | Article | PubMed Abstract | PubMed Full Text

78. Nayak DP, Balogun RA, Yamada H, Zhou ZH and Barman S. Influenza virus 
Mayank al. Virology Discovery 2014,

morphogenesis and budding. Virus Res. 2009; 143:147-61. | Article | PubMed Abstract | PubMed Full Text

79. Bruce EA, Digard P and Stuart AD. The Rab11 pathway is required for influenza A virus budding and filament formation. J Virol. 2010; 84:5848-59. | Article | PubMed Abstract | PubMed Full Text

\section{Citation:}

Mayank AK, Sharma S, Deshwal RK and Lal SK. Genome-wide screens - a systematic approach to redefine the influenza A virus-host crosstalk. Virol Discov. 2014; 2:2.

http://dx.doi.org/10.7243/2052-6202-2-2 